\title{
Gordonia rhizosphera sp. nov. isolated from the mangrove rhizosphere
}

\author{
Mariko Takeuchi and Kazunori Hatano
}

Author for correspondence: Mariko Takeuchi. Tel: +8162906555 . Fax: +8162906814 .

Institute for Fermentation, Osaka, 17-85, Jusohonmachi 2-chome, Yodogawa-ku, Osaka 532-8686, Japan

\begin{abstract}
The taxonomic position of bacterial strain $141^{\top}$, isolated from the mangrove rhizosphere, has been clarified by phenotypic, chemotaxonomic and phylogenetic studies. The strain possesses wall chemotype IV, $\mathrm{MK}-9\left(\mathrm{H}_{2}\right)$ as the predominant menaquinone, relatively long-chain mycolic acids (56-64 carbon atoms) and straight-chain saturated and monounsaturated fatty acids with a small amount of tuberculostearic acid. The G+C content of the DNA is $66.8 \mathrm{~mol} \%$. Similarity values for genes encoding 165 rRNA indicated that strain $141^{\top}$ represents a new species within the genus Gordonia for which the name Gordonia rhizosphera sp. nov. is proposed. The type strain of G. rhizosphera is $141^{\top}$ ( = IFO 16068').
\end{abstract}

Keywords: Gordonia rhizosphera sp. nov., mangrove rhizosphere

\section{INTRODUCTION}

Mangrove forests in Japan are mainly distributed in the Okinawa prefecture where complex environments have formed under the influence of tidal ebb and flow, the influx of fresh water, and high temperature and humidity in the subtropical and tropical climates. The soils in such environments are muddy and are reported to be anoxic, low in nutrients and to have higher concentrations of heavy metals and higher salinity than terrestrial soils (Ito \& Nakagiri, 1997; Wakushima et al., 1994).

Recently, Hatano (1997) examined actinomycete populations in rhizosphere soils of six kinds of mangrove forest on the Iriomote and Ishigaki islands in Japan and suggested that the mangrove rhizosphere is a good source for isolating new and diverse actinomycetes.

In the course of an ecological study of actinomycetes in mangrove rhizospheres, six colonies of similar appearance were isolated from the surface of fine roots (two colonies) and soil (four colonies) in the rhizosphere of Bruguiera gymnorrhiza Lamk. in the Shiira River estuary, Iriomote Island. Strain $141^{\mathrm{T}}$ used in this study is representative of these isolates. This organism is a rod-shaped bacterium with all of the characteristic chemotaxonomic markers of the genus Gordonia (Stackebrandt et al., 1988), including wall chemotype IV (meso-diaminopimelic acid, arabinose and galac-

Abbreviation: TBSA, tuberculostearic acid.

The DDBJ accession number for the $16 \mathrm{~S}$ rDNA sequence of strain $141^{\top}$ is $\mathrm{AB} 004729$. tose) (Lechevalier \& Lechevalier, 1970), an MK-9( $\left.\mathrm{H}_{2}\right)$ type menaquinone and mycolic acids.

In this study we describe the morphological, physiological and genetic characteristics of strain $141^{\mathrm{T}}$ (= IFO $16068^{\mathrm{T}}$ ) and propose that this strain represents a new species within the genus Gordonia, Gordonia rhizosphera sp. nov. This is the first report of the appearance of Gordonia species in the mangrove rhizosphere.

\section{METHODS}

Bacterial strain and cultivation. Samples were collected in late October 1995 from the rhizosphere of Bruguiera gymnorrhiza Lamk. in the Shiira River estuary, Iriomote Island, Japan. Strain $141^{\mathrm{T}}$ ( = IFO $16068^{\mathrm{T}}$ ) was isolated from soil and the surface of fine roots by the method described by Hayakawa \& Nonomura $(1987,1989)$. Gordonia aichiensis IFO $16046^{\mathrm{T}}$ (Klatte et al., 1994), Gordonia amarae IFO $15530^{\mathrm{T}}$ (Klatte et al., 1994; Ruimy et al., 1994), Gordonia bronchialis IFO $16047^{\mathrm{T}}$ (Stackebrandt et al., 1988), Gordonia rubropertincta IFO 16048 ${ }^{\mathrm{T}}$ (Stackebrandt et al., 1988), Gordonia sputi IFO 16049 ${ }^{\mathrm{T}}$ (Riegel et al., 1994; Stackebrandt et al., 1988) and Gordonia terrae IFO $16050^{\mathrm{T}}$ (Stackebrandt et al., 1988) were used for comparison of physiological properties and for DNA-DNA hybridization tests. Each strain was cultivated aerobically at $28^{\circ} \mathrm{C}$ in a peptone/yeast extract medium (PY medium) containing $1 \%$ peptone, $0.2 \%$ yeast extract, $0 \cdot 2 \% \mathrm{NaCl}$ and $0 \cdot 2 \%$ D-glucose (pH 7.2). Cells used for biochemical tests were harvested by centrifugation during the stationary phase, washed with water and lyophilized.

Morphological and physiological property tests. Cell morphology was determined by phase-contrast microscopy following growth on PY agar. Motility was determined by 
the hanging drop method. Assimilation of organic acids was tested in a medium containing $0.5 \%$ organic acid (sodium salt), $0.1 \% \mathrm{NH}_{4} \mathrm{NO}_{3}, 0 \cdot 1 \% \mathrm{KH}_{2} \mathrm{PO}_{4}, 0.05 \% \mathrm{MgSO}_{4} .7 \mathrm{H}_{2} \mathrm{O}$ and $0.02 \% \mathrm{KCl}$ (pH 7.2). Acid production from carbohydrates was studied in a medium containing $1 \%$ peptone, $0.5 \% \mathrm{NaCl}, 0.003 \%$ bromocresol purple and $0.5 \%$ carbohydrate (pH 7.2) (Cowan, 1974).

Cell wall analysis. Cell walls were prepared from about $500 \mathrm{mg}$ (dry wt) bacterial cells as described by Schleifer \& Kandler (1972). Amino acids in the acid hydrolysate of the cell walls were identified by HPLC as described by Yokota $e t$ al. (1993). Cell wall sugars were analysed as described by Mikami \& Ishida (1983). The glycolyl test was performed by the method of Uchida \& Aida (1977).

Cellular fatty acid analysis. Fatty acids were extracted from dried cells, purified and analysed by GC-MS with a GCMSQP5000 spectrometer (Shimadzu) combined with a CLASS5000 MS Workstation computer system. GLC analyses were performed with a GC-17A gas chromatograph (Shimadzu). A BPX70 capillary column (SGE) containing $70 \%$ cyanopropyl-equivalent modified siloxane $(50 \mathrm{~m} \times 0.25 \mathrm{~mm})$ was used at $80^{\circ} \mathrm{C}$ for $2 \mathrm{~min}, 80-150^{\circ} \mathrm{C}$ at $15^{\circ} \mathrm{C} \mathrm{min} \mathrm{m}^{-1}$, $150-250^{\circ} \mathrm{C}$ at $8^{\circ} \mathrm{C} \mathrm{min}^{-1}$ and then at $250^{\circ} \mathrm{C}$ for $5 \mathrm{~min}$ with helium as carrier gas $\left(1.4 \mathrm{ml} \mathrm{min}^{-1}\right)$.

Mycolic acid analysis. Mycolic acids were analysed by the method of Yano et al. (1978). The dried cells were hydrolysed with $25 \% \mathrm{KOH} /$ methanol for $16-18 \mathrm{~h}$ at $80^{\circ} \mathrm{C}$ and mycolic acids were extracted with $n$-hexane after acidification to $\mathrm{pH} 2$ with $6 \mathrm{M} \mathrm{HCl}$. Trimethylsilyl (TMS) derivatives of methyl mycolates were analysed by GC (HP5890 series II; Hewlett-Packard) equipped with a flame ionization detector on a capillary column $(15 \mathrm{~m} \times 0.2 \mathrm{~mm})$ coated with dimethyl silicone (SPB-1; Supelco) with helium as carrier gas $(1 \mathrm{ml}$ $\left.\min ^{-1}\right)$. The oven temperature was programmed from 300 to $350^{\circ} \mathrm{C}$ at $4^{\circ} \mathrm{C} \mathrm{min} \mathrm{m}^{-1}$, holding the final temperature for $60 \mathrm{~min}$. TMS derivatives of methyl mycolates were identified by capillary GC-MS. GC-MS was performed on a JEOL SX102A mass spectrometer combined with an electron impact (EI) ion source.

DNA base composition. DNA was obtained by the method of Saito \& Miura (1963). The G $+C$ content of the DNA was determined by the method of Mesbah et al. (1989) after treatment with $\mathrm{Pl}$ nuclease and alkaline phosphatase, and by HPLC by using a model LC-6AD instrument (Shimadzu) equipped with a Cosmosil 5C18-AR column $(150 \times 4.6 \mathrm{~mm}$; Nacalai Tesque) (Tamaoka \& Komagata, 1984).

DNA-DNA hybridization. DNA-DNA hybridization was carried out fluorometrically in microdilution wells by using biotinylated DNA (Ezaki et al., 1989).

Phylogenetic analysis. 16S rRNA-specific DNA was amplified by PCR (Hiraishi, 1992; Hiraishi et al., 1994) and sequenced directly with the Thermo Sequenase Fluorescent Labelled Primer Cycle Sequencing Kit with 7-deaza-dGTP (Amersham) and a Pharmacia Model ALF DNA Sequencer following the manufacturers' instructions. Nucleotide substitution rates $\left(K_{\text {nuc }} ;\right.$ Kimura, 1980) were calculated by using the CLUSTAL V software package (Higgins et al., 1992) and phylogenetic trees were constructed by the neighbourjoining method (Saitou \& Nei, 1987). The topology of the phylogenetic tree was evaluated by the bootstrap resampling method of Felsenstein (1985) with 1000 replicates.

Nucleotide sequence accession numbers. The DDBJ, GenBank and EMBL accession numbers for the 16S rDNA sequences used for comparison are as follows: Arthrobacter globiformis DSM 20124 ${ }^{\mathrm{T}}$, M23411; Brevibacterium linens DSM 20425 , X77451; Corynebacterium amycolatum NCTC $3224^{\mathrm{T}}$, X84244; Corynebacterium bovis NCTC $3224^{\mathrm{T}}$, X84444; Corynebacterium diphtheriae NCTC $11397^{\mathrm{T}}$, X84248; Corynebacterium glutamicum NCIB $10025^{\mathrm{T}}$, X84257; Dietzia maris DSM 43672 ${ }^{\mathrm{T}}$, X79290; Gordonia aichiensis DSM 43978 ${ }^{\mathrm{T}}$, X80633; Gordonia amarae DSM $43392^{\mathrm{T}}$ ，X80635; Gordonia bronchialis DSM $43247^{\mathrm{T}}$, X79287; Gordonia hirsuta DSM 44140T , X93485; Gordonia hydrophobica DSM 44015 , X87340; Gordonia rubropertincta DSM $43197^{\mathrm{T}}$, X80632; Gordonia sputi DSM 43896 ${ }^{\mathrm{T}}$, X80634; Gordonia terrae DSM 43249 ${ }^{\mathrm{T}}$, X79286; Kineococcus aurantiacus IFO $15268^{\mathrm{T}}$, AB007420; Mycobacterium bovis ATCC 12910 ${ }^{\mathrm{T}}$, X55589; Mycobacterium intracellulare ATCC 15985, X52927; Nocardia asteroides ATCC 3306, X57949; Rhodococcus fascians DSM 43188, X53204; Rhodococcus erythropolis DSM 43066 ${ }^{\mathrm{T}}$, X79289; Rhodococcus rhodochrous DSM 43241 ${ }^{\mathrm{T}}$, X79288; Skermania piniformis (Chun et al., 1997) IFO 15059 ${ }^{\mathrm{T}}$, Z35435; Terrabacter tumescens NCIB $8914^{\mathrm{T}}$, X53215; and Tsukamurella paurometabola DSM $20162^{\mathrm{T}}$, X53206.

\section{RESULTS}

\section{Population in mangrove rhizosphere}

Six colonies were isolated from the rhizosphere soils of six types of mangrove forest on Iriomote and Ishigaki islands, Japan: two colonies from the surface of fine roots of Bruguiera gymnorrhiza Lamk. and four colonies from rhizosphere soils. All colonies were pink to orange with irregular margins and flat, rough surfaces on HV agar (Hayakawa \& Nonomura, 1987) and PY agar. The actinomycete population of the colonies was about $5 \%(6 / 117$ colonies $)$.

\section{Chemotaxonomic characteristics}

The results of this study are shown in Tables 1 and 2 along with data for related taxa. The cell wall of strain $141^{\mathrm{T}}$ contained arabinose and galactose (molar ratio about $1: 1$ ) as major cell wall sugars and mesodiaminopimelic acid as the only diamino acid, properties characteristic of wall chemotype IV sensu Lechevalier \& Lechevalier (1970). $N$-Glycolated muramic acid moieties of peptidoglycan were present. MK$9\left(\mathrm{H}_{2}\right)$ was found to be the predominant menaquinone. Whole-organism fatty acids were mainly straightchain, saturated and monounsaturated $\left(27 \% \mathrm{C}_{16: 0}\right.$, $13 \% \mathrm{C}_{17: 0}, 27 \% \mathrm{C}_{18: 1}$ ) with $3 \%$ tuberculostearic acid (10-methyl $\mathrm{C}_{18: 0}$, TBSA). As shown in Table 2, the amount of TBSA in strain $141^{\mathrm{T}}$ was smaller than that in other species of the genus Gordonia, but it did not change with culture conditions (data not shown). The mycolic acids of strain $141^{\mathrm{T}}$, as determined from trimethylsilylated derivatives by high-temperature $\mathrm{GC}$, were similar in size as described for members of the genus Gordonia, having an overall range of 56-64 carbon atoms $\left(7 \% \mathrm{C}_{58}, 5 \% \mathrm{C}_{59}, 26 \% \mathrm{C}_{60}, 10 \% \mathrm{C}_{61}\right.$, $34 \% \mathrm{C}_{62}, 6 \% \mathrm{C}_{64}$ and traces of $\mathrm{C}_{56}, \mathrm{C}_{57}$ and $\mathrm{C}_{63}$ ) with a mean chain length of between 60 and 62 carbon atoms. The mycolic acids were mainly composed of $\mathrm{C}_{42-46}$-dienoic or -trienoic $\beta$-units and $\mathrm{C}_{16-18}$-saturated 
Table 1. Differential characteristics of $G$. rhizosphera and related taxa containing mycolic acids

Data are from this and other studies (Chun et al., 1997; Collins \& Cummins, 1986; Goodfellow, 1992; Rainey et al., 1995).

\begin{tabular}{|c|c|c|c|c|c|c|}
\hline Taxon & $\begin{array}{l}\text { Aerial } \\
\text { hyphae }\end{array}$ & $\begin{array}{l}\text { Predominant } \\
\text { menaquinone }\end{array}$ & $\begin{array}{c}\mathbf{G}+\mathbf{C} \text { content } \\
(\mathrm{mol} \%)\end{array}$ & $\begin{array}{c}\text { Fatty acid } \\
\text { composition* }\end{array}$ & $\begin{array}{l}\text { No. of carbon } \\
\text { atoms in } \\
\text { mycolic acids }\end{array}$ & $\begin{array}{l}\text { Acyl group of } \\
\text { muramic acid }\end{array}$ \\
\hline Gordonia rhizosphera & - & MK-9 $\left(\mathrm{H}_{2}\right)$ & $66 \cdot 8$ & S, U, TBSA & $56-64$ & $N$-Glycolated \\
\hline Corynebacterium & - & MK-8( $\left.\mathrm{H}_{2}\right)$ or MK-9 $\left(\mathrm{H}_{2}\right)$ & $51-67$ & $\mathrm{~S}, \mathrm{U},(\mathrm{TBSA}) \dagger$ & $22-36$ & $\mathrm{~N}$-Acetylated \\
\hline Dietzia & - & MK-8 $\left(\mathrm{H}_{2}\right)$ & 73 & $\mathrm{~S}, \mathrm{U}, \mathrm{TBSA}$ & $34-38$ & $N$-Acetylated \\
\hline Gordonia & - & MK-9(H $)$ & $63-69$ & S, U, TBSA & $48-66$ & $N$-Glycolated \\
\hline Mycobacterium & - & MK-9 $\left(\mathrm{H}_{2}\right)$ & $61-71$ & S, U, TBSA & $60-90$ & $N$-Glycolated \\
\hline Nocardia & + & MK- $8\left(\mathrm{H}_{4}, \omega\right.$-cycl $)$ & $64-72$ & S, U, TBSA & $44-60$ & $N$-Glycolated \\
\hline Rhodococcus & - & MK- $8\left(\mathrm{H}_{2}\right)$ & $63-73$ & S, U, TBSA & $34-52$ & $N$-Glycolated \\
\hline Skermania & + & MK- $8\left(\mathrm{H}_{4}, \omega-\right.$ cycl $)$ & $73 \cdot 5$ & S, U, TBSA & $58-64$ & $\mathrm{~N}$-Glycolated \\
\hline Tsukamurella & - & MK-9 & $67-68$ & S, U, TBSA & $64-68$ & $\mathrm{~N}$-Glycolated \\
\hline
\end{tabular}

*S, Saturated; U, monounsaturated.

†TBSA is present in Corynebacterium ammoniagenes, Corynebacterium bovis, Corynebacterium cystitidis, Corynebacterium minutissimum, Corynebacterium pilosum, Corynebacterium urealyticum and Corynebacterium variabilis (Herrera-Alcaraz et al., 1990; Pitcher et al., 1992).

Table 2. Cellular fatty acids of G. rhizosphera and type strains of Gordonia species

\begin{tabular}{|c|c|c|c|c|c|c|c|c|c|}
\hline \multirow[t]{2}{*}{ Strain } & \multicolumn{9}{|c|}{ Cellular fatty acid composition (\%) } \\
\hline & $\mathrm{n}-14: 0$ & $n-15: 0$ & $n-16: 1$ & n-16:0 & n-17:1 & $\mathrm{n}-17: 0$ & n-18:1 & $n-18: 0$ & TBSA \\
\hline G. rhizosphera IFO $16068^{\mathrm{T}}$ & 3 & 4 & 4 & 27 & 7 & 13 & 27 & 11 & 3 \\
\hline G. aichiensis IFO $16046^{\mathrm{T}}$ & 8 & 7 & 8 & 31 & & 3 & 5 & 2 & 25 \\
\hline G. amarae IFO $15530^{\mathrm{T}}$ & & & 9 & 36 & & & 15 & 20 & 20 \\
\hline G. bronchialis IFO $16047^{\mathrm{T}}$ & 9 & 5 & 4 & 47 & & 14 & 6 & 6 & 9 \\
\hline G. hirsuta DSM $44140^{\mathrm{T} *}$ & 2 & & $17 \dagger$ & 30 & $1 \ddagger$ & 1 & $30 \S$ & 3 & 17 \\
\hline G. hydrophobica DSM $44015^{\mathrm{T} *}$ & 1 & 4 & 13 & 27 & $4 \grave{\ddagger}$ & 4 & $14 \S$ & & 17 \\
\hline G. rubropertincta IFO $16048^{\mathrm{T}}$ & & & 15 & 37 & & & 19 & 9 & 19 \\
\hline G. sputi IFO $16049^{\mathrm{T}}$ & 2 & 2 & & 44 & 2 & 2 & 29 & & 15 \\
\hline G. terrae IFO $16050^{\mathrm{T}}$ & 4 & 1 & 10 & 32 & & & 16 & 19 & 18 \\
\hline
\end{tabular}

* Data from Klatte et al. $(1994,1996)$.

$\dagger$ Total amount of n-16:1cis 9 and n-16:1 cis 10 .

$\ddagger \mathrm{n}-17: 1$ cis 9 .

$\S \mathrm{n}-18: 1$ cis 9 .

$\alpha$-units. The $\mathrm{G}+\mathrm{C}$ content of the DNA was $66.8 \mathrm{~mol} \%$.

\section{Physiological characteristics}

Strain $141^{\mathrm{T}}$ was a Gram-positive, non-motile, strictly aerobic and rod-shaped bacterium. Pink to orange colonies with irregular margins and flat, rough surfaces were formed on various media. Mycelium was not formed. The strain was catalase-positive and oxidasenegative. Cells were $0.2-0.4 \mu \mathrm{m}$ wide and $0.4-1.0 \mu \mathrm{m}$ long. L-Alanine, citrate and gluconate were utilized, but the following carbon substrates were not used or used weakly: galactose, inositol, rhamnose, ribose, sucrose, aspartate, benzoate, propionate, succinate, leucine, proline, L-valine, acetamide and $\mathrm{N}$-acetylglucosamine. Acids were not produced from galactose, inositol, sorbitol, sucrose or trehalose, but were produced weakly from rhamnose. Table 3 shows some of the diagnostic and differentiating characteristics of strain $141^{\mathbf{T}}$ and other species of the genus Gordonia.

\section{Analysis of 16S rDNA}

The nucleotide sequence of 16S rDNA, enzymically amplified from strain $141^{\mathrm{T}}$, was determined by direct automated sequencing. A total of $1475 \mathrm{nt}$ were sequenced and the primary structure was aligned with 
Table 3. Diagnostic and differentiating characteristics of $G$. rhizosphera and other species of the genus Gordonia

Data are from other studies (Bendinger et al., 1995; Klatte et al., 1994, 1996; Riegel et al., 1994; Ruimy et al., 1994; Stackebrandt et al., 1988).

\begin{tabular}{|c|c|c|c|c|c|c|c|c|c|}
\hline Characteristic & G. rhizosphera & G. aichiensis & G. amarae & G. bronchialis & G. hirsuta & G. hydrophobica & G. rubropertincta & G. sputi & G. terrae \\
\hline Colour of colonies & Pink to orange & Pinkish to orange & Tannish to white & Pink to red & $\begin{array}{c}\text { White to light } \\
\text { yellow }\end{array}$ & Tannish to white & Pink to red & Salmon & Pink to orange \\
\hline \multicolumn{10}{|l|}{ Assimilation of:* } \\
\hline Galactose & - & + & - & - & $\mathrm{ND}$ & + & + & + & + \\
\hline Inositol & - & - & - & + & + & - & ND & - & - \\
\hline Rhamnose & $+w$ & - & - & $\mathrm{v}$ & - & - & $\mathrm{v}$ & - & $\mathrm{v}$ \\
\hline Ribose & - & - & + & - & - & - & + & - & - \\
\hline Sucrose & - & - & + & + & - & + & + & - & + \\
\hline Aspartate & - & + & - & - & - & - & - & - & - \\
\hline Benzoate & - & - & - & - & - & - & + & - & + \\
\hline Citrate & + & + & + & - & - & + & - & + & + \\
\hline Gluconate & + & - & - & + & - & - & + & - & - \\
\hline Succinate & - & - & - & + & - & + & - & + & - \\
\hline L-Alanine & + & + & - & + & - & - & + & - & - \\
\hline Leucine & $+w$ & - & - & + & + & - & - & - & - \\
\hline Proline & $+w$ & - & + & + & - & + & - & - & $\ldots$ \\
\hline L-Valine & $+w$ & - & + & + & - & + & - & - & - \\
\hline Acetamide & - & - & - & $\mathrm{v}$ & - & + & - & - & - \\
\hline \multicolumn{10}{|l|}{ Acid produced from:* } \\
\hline Rhamnose & $+w$ & ND & $\mathrm{ND}$ & + & ND & ND & ND & ND & - \\
\hline Trehalose & - & ND & ND & + & ND & ND & ND & ND & + \\
\hline $\begin{array}{l}\text { Mean no. of carbon atoms } \\
\text { in mycolic acids }\end{array}$ & $60-62$ & 62 & $50-52$ & 64 & $60-64$ & $58-60$ & $58-59$ & $61-62$ & 58 \\
\hline $\begin{array}{l}\text { Presence of } \\
16: 1 \text { fatty acid }\end{array}$ & + & + & + & + & + & + & + & - & + \\
\hline
\end{tabular}

${ }^{*}+$, Positive reaction; - , negative reaction; $+\mathrm{w}$, weakly positive reaction; $\mathrm{v}$, variable reaction; ND, not determined.

those of 25 representative members of wall chemotype IV taxa, containing mycolic acids, and other related organisms. Sequence similarity calculations were based on $1077 \mathrm{nt}$, because only partial sequences were available in some of the reference strains. A phylogenetic tree (Fig. 1) was constructed on the basis of the distance matrix data. It showed that strain $141^{\mathrm{T}}$ formed a coherent cluster with species of the genus Gordonia and represents a distinct lineage within the genus. The closest related species was $G$. bronchialis and the level of 16S rDNA sequence similarity between strain $141^{\mathrm{T}}$ and $G$. bronchialis was $99 \cdot 2 \%$ (data not shown).

\section{DNA-DNA hybridization}

The levels of DNA-DNA relatedness between strain $141^{\mathrm{T}}$ and $G$. bronchialis IFO $16047^{\mathrm{T}}$ and between these strains and other species of the genus Gordonia were $29-31 \%$ and $7-29 \%$, respectively (Table 4 ).

\section{DISCUSSION}

From the results of this work, it is evident that strain $141^{\mathrm{T}}$ represents a new Gordonia species. It has all of the characteristic chemotaxonomic markers of this genus, including an MK-9 $\left(\mathrm{H}_{2}\right)$-type menaquinone, mycolic acids and straight-chain saturated and unsaturated fatty acids together with TBSA, and it can be differentiated from all previously described Gordonia species on the basis of physiological properties and fatty acid profiles, as well as DNA-DNA hybridization data. We propose that strain $141^{\mathrm{T}}\left(=\right.$ IFO $\left.16068^{\mathrm{T}}\right)$ should be classified as a new species of the genus Gordonia, Gordonia rhizosphera sp. nov.

Eight species have hitherto been accommodated within the genus Gordonia. They are widely distributed in various environments, such as human sputum (Klatte et al., 1994; Riegel et al., 1994; Stackebrandt et al., 1988), activated-sludge sewage-treatment plants (Lemmer \& Kroppenstedt, 1984), fibre bark compost of a large-scale biofilter used for biological odour abatement of biofilters for waste gas treatment (Bendinger et al., 1995; Klatte et al., 1996) and soil (Klatte et al., 1994; Stackebrandt et al., 1988). G. rhizosphera was isolated from the surface of fine roots or soil in the mangrove rhizosphere. This is the first report of the appearance of Gordonia species in the mangrove rhizosphere, where complex environments are formed involving muddy, anoxic conditions and lower nutrient levels than terrestrial soils (Wakushima et al., 1994).

\section{Description of Gordonia rhizosphera sp. nov.}

Gordonia rhizosphera (rhi.zo'spher.a. L. fem. m. rhizo root; Gr. adj. sphera sphere; L. fem. adj. rhizosphera within the sphere of the root).

Cells are Gram-positive, non-motile rods, $0 \cdot 2-0 \cdot 4 \mu \mathrm{m}$ wide and $0.4-1.0 \mu \mathrm{m}$ long. Rough, pink to orange colonies are formed on PY agar or HV agar and no aerial mycelia or diffusible pigments are produced. Catalase-positive and oxidase-negative. L-Alanine, citrate and gluconate are utilized, but the following 


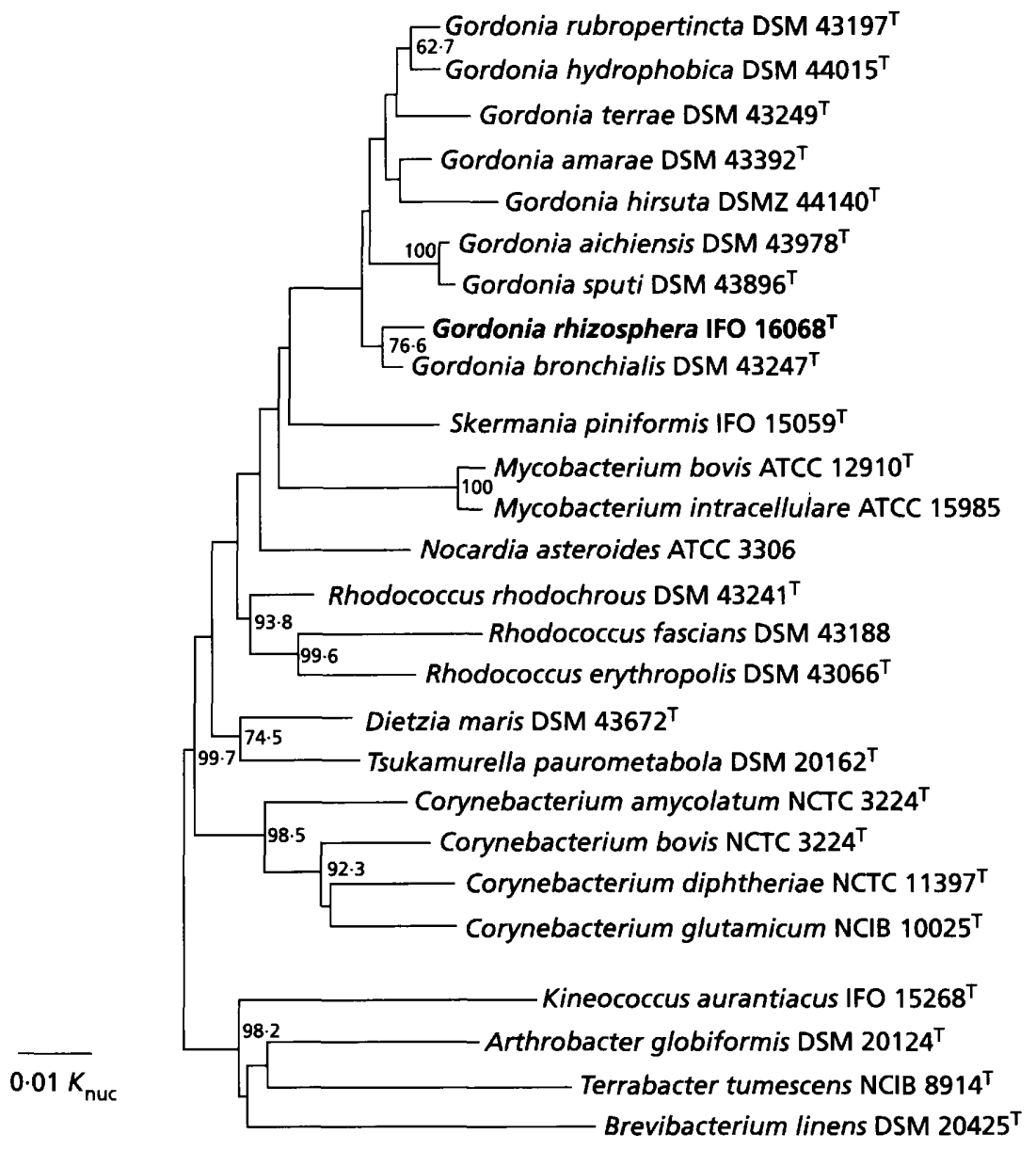

Fig. 1. Unrooted phylogenetic tree displaying the relationship of $G$. rhizosphera strain $141^{\top}$ (=IFO $16068^{\top}$ ) to reference organisms. The numerals indicate the percentages of bootstrap samplings, derived from 1000 samples, supporting the internal branches (Felsenstein, 1985).
Table 4. DNA-DNA homology values

\begin{tabular}{|c|c|c|c|}
\hline \multirow[t]{2}{*}{ Species } & \multirow[t]{2}{*}{ IFO no. } & \multicolumn{2}{|c|}{$\begin{array}{l}\text { Percentage reassociation } \\
\text { with: }\end{array}$} \\
\hline & & IFO $16068^{T}$ & IFO $16047^{\mathrm{r}}$ \\
\hline G. rhizosphera & $16068^{T}$ & 100 & 30 \\
\hline G. aichiensis & $16046^{\mathrm{T}}$ & 30 & 28 \\
\hline G. amarae & $15530^{\mathrm{T}}$ & 10 & 23 \\
\hline G. bronchialis & $16047^{\mathrm{T}}$ & 31 & 100 \\
\hline G. rubropertincta & $16048^{\mathrm{T}}$ & 11 & 10 \\
\hline G. sputi & $16049^{\mathrm{T}}$ & 10 & 12 \\
\hline G. terrae & $16050^{\mathrm{T}}$ & 13 & 7 \\
\hline
\end{tabular}

carbon substrates are not used or used weakly: galactose, inositol, rhamnose, ribose, sucrose, aspartate, benzoate, propionate, succinate, leucine, proline, L-valine, acetamide and $N$-acetylglucosamine. Acids are not produced from galactose, inositol, sorbitol, sucrose or trehalose, but are produced weakly from rhamnose. Cell wall is of chemotype IV sensu Lechevalier \& Lechevalier (1970), containing mesodiaminopimelic acid, arabinose and galactose. $N$ Glycolated muramic acid moieties of peptidoglycan are present. Predominant isoprenoid quinone is menaquinone MK-9 $\left(\mathrm{H}_{2}\right)$. Mycolic acids with 56-64 carbon atoms are present. Major amounts of straight-chain, saturated and monounsaturated fatty acids and TBSA are found. $\mathrm{G}+\mathrm{C}$ content of the DNA is $66.8 \mathrm{~mol} \%$. Habitat is mangrove rhizosphere. Type strain is strain $141^{\mathrm{T}}\left(=\right.$ IFO $\left.16068^{\mathrm{T}}\right)$.

\section{ACKNOWLEDGEMENTS}

We thank Ikuya Yano and Yukiko Nishiuchi, Osaka City University Medical School, for help in analysing mycolic acids and valuable suggestions. This work was supported by Fujiwara Natural History Foundation.

\section{REFERENCES}

Bendinger, B., Rainey, F. A., Kroppenstedt, R. M., Moormann, M. \& Klatte, S. (1995). Gordonia hydrophobica sp. nov., isolated from biofilters for waste gas treatment. Int J Syst Bacteriol 45, 544-548.

Chun, J., Blackall, L. L., Kang, S.-O., Hah, Y. C. \& Goodfellow, M. (1997). A proposal to reclassify Nocardia pinensis Blackall et al. as Skermania piniformis gen. nov., comb. nov. Int $J$ Syst Bacteriol 47, 127-131.

Collins, M. D. \& Cummins, C. S. (1986). Genus Corynebacterium Lehmann and Neumann 1896, 350 AL. In Bergey's Manual of Systematic Bacteriology, vol. 2, pp. 1266-1283. Edited by P. H. 
A. Sneath, N. S. Mair, M. E. Sharpe \& J. G. Holt. Baltimore: Williams \& Wilkins.

Cowan, S. T. (1974). Cowan and Steel's Manual for the Identification of Medical Bacteria. Cambridge: Cambridge University Press.

Ezaki, T., Hashimoto, Y. \& Yabuuchi, E. (1989). Fluorometric deoxyribonucleic acid-deoxyribonucleic acid hybridization in microdilution wells as an alternative to membrane filter hybridization in which radioisotopes are used to determine genetic relatedness among bacterial strains. Int $J$ Syst Bacteriol 39, 224-229.

Felsenstein, J. (1985). Confidence limits on phylogenies: approach using the bootstrap. Evolution 39, 783-791.

Goodfellow, M. (1992). The family Nocardiaceae. In The Prokaryotes, 2nd edn, pp. 1188-1213. Edited by A. Balows, H. G. Trüper, M. Dworkin, W. Harder \& K.-H. Schleifer. New York: Springer.

Hatano, K. (1997). Actinomycete populations in mangrove rhizospheres. IFO Res Commun 18, 26-31.

Hayakawa, M. \& Nonomura, H. (1987). Efficacy of artificial humic acid as a selective nutrient in HV agar used for the isolation of soil actinomycetes. J Ferment Technol 65, 609-616.

Hayakawa, M. \& Nonomura, H. (1989). A new method for the intensive isolation of actinomycetes from soil. Actinomycetologica 3, 95-104.

Herrera-Alcaraz, E. A., Valero-Guillén, P. L., Martin-Luengo, F. \& Soriano, F. (1990). Taxonomic implications of the chemical analysis of the D2 group of corynebacteria. FEMS Microbiol Lett 72, 341-344.

Higgins, D. G., Bleasby, A. J. \& Fuchs, R. (1992). CluSTAL v: improved software for multiple sequence alignment. Comput Appl Biosci 8, 189-191.

Hiraishi, A. (1992). Direct automated sequencing of 16S rRNA amplified by polymerase chain reaction from bacterial culture without DNA purification. Lett Appl Microbiol 15, 210-213.

Hiraishi, A., Shin, Y. K., Ueda, Y. \& Sugiyama, J. (1994). Automated sequencing of PCR-amplified 16S rRNA on 'Hydrolink' gels. J Microbiol Methods 19, 145-154.

Ito, T. \& Nakagiri, A. (1997). A mycofloral study on mangrove mud in Okinawa, Japan. IFO Res Commun 18, 32-39.

Kimura, M. (1980). A simple method for estimating evolutionary rates of base substitutions through comparative studies of nucleotide sequences. $J \mathrm{Mol}$ Evol 16, 111-120.

Klatte, S., Rainey, F. A. \& Kroppenstedt, R. M. (1994). Transfer of Rhodococcus aichiensis Tsukamura 1982 and Nocardia amarae Lechevalier and Lechevalier 1974 to the genus Gordonia as Gordonia aichiensis comb. nov. and Gordonia amarae comb. nov. Int J Syst Bacteriol 44, 769-773.

Klatte, S., Kroppenstedt, R. M., Schumann, P., Altendorf, K. \& Rainey, F. A. (1996). Gordonia hirsuta sp. nov. Int J Syst Bacteriol 46, 876-880.

Lechevalier, M. P. \& Lechevalier, H. A. (1970). Chemical composition as criterion in the classification of aerobic actinomycetes. Int J Syst Bacteriol 20, 435-443.

Lemmer, H. \& Kroppenstedt, R. M. (1984). Chemotaxonomy and physiology of some actinomycetes isolated from scumming activated sludge. Syst Appl Microbiol 5, 124-135.
Mesbah, M., Premachandran, U. \& Whitman, W. B. (1989). Precise measurement of the $\mathrm{G}+\mathrm{C}$ content of deoxyribonucleic acid by high-performance liquid chromatography. Int $J$ Syst Bacteriol 39, 159-167.

Mikami, H. \& Ishida, Y. (1983). Post-column fluorometric detection of reducing sugars in high-performance liquid chromatography using arginine. Bunseki Kagaku 32, E207-E210.

Pitcher, D., Soto, A., Soriano, F. \& Valero-Guillén, P. (1992). Classification of coryneform bacteria associated with human urinary tract infection (group D2) as Corynebacterium urealyticum sp. nov. Int J Syst Bacteriol 42, 178-181.

Rainey, F. A., Klatte, S., Kroppenstedt, R. M. \& Stackebrandt, E. (1995). Dietzia, a new genus including Dietzia maris comb. nov., formerly Rhodococcus maris. Int J Syst Bacteriol 45, 32-36.

Riegel, P., Kamne-Fotso, M. V., de Briel, D., Prévost, G., Jehl, F., Piémont, Y. \& Monteil, H. (1994). Rhodococcus chubuensis Tsukamura 1982 is a later subjective synonym of Gordonia sputi (Tsukamura 1978) Stackebrandt 1989 comb. nov. Int J Syst Bacteriol 44, 764-768.

Ruimy, R., Boiron, P., Boivin, V. \& Christen, R. (1994). A phylogeny of the genus Nocardia deduced from the analysis of smallsubunit ribosomal DNA sequences, including transfer of Nocardia amarae to the genus Gordonia as Gordonia amarae comb. nov. FEMS Microbiol Lett 123, 261-268.

Saito, H. \& Miura, K. (1963). Preparation of transforming deoxyribonucleic acid by phenol treatment. Biochim Biophys Acta 72, 619-629.

Saitou, N. \& Nei, M. (1987). The neighbor-joining method: a new method for reconstructing phylogenetic trees. Mol Biol Evol 4, $406-425$.

Schleifer, K. H. \& Kandler, O. (1972). Peptidoglycan types of bacterial cell walls and their taxonomic implications. Bacteriol Rev 36, 407-477.

Stackebrandt, E., Smida, J. \& Collins, M. D. (1988). Evidence of phylogenetic heterogeneity within the genus Rhodococcus: revival of the genus Gordonia (Tsukamura). J Gen Appl Microbiol 34, 341-348.

Tamaoka, J. \& Komagata, K. (1984). Determination of DNA base composition by reversed-phase high performance liquid chromatography. FEMS Microbiol Lett 25, 125-128.

Uchida, K. \& Aida, K. (1977). Acyl type of bacterial cell wall: its simple identification by colorimetric method. J Gen Appl Microbiol 23, 249-260.

Wakushima, S., Kuraishi, S. \& Sakurai, N. (1994). Soil salinity and $\mathrm{pH}$ in Japanese mangrove forests and growth of cultivated mangrove plants in different soil conditions. $J$ Plant Res 107 , 39-46.

Yano, I., Kageyama, K., Ohno, Y., Masui, M., Kusunose, E., Kusunose, M. \& Akimori, N. (1978). Separation and analysis of molecular species of mycolic acids in Nocardia and related taxa by gas chromatography mass spectrometry. Biomed Mass Spectrom 5, 14-23.

Yokota, A., Takeuchi, M. \& Weiss, N. (1993). Proposal of two new species in the genus Microbacterium: Microbacterium dextranolyticum sp. nov. and Microbacterium aurum sp. nov. Int J Syst Bacteriol 43, 549-554. 